Andrzej A. ZięBA

(D) https://orcid.org/0000-0003-4922-6249

Uniwersytet JagiellońsKi w Krakowie

\title{
INAUGURACJA PRAC \\ OŚRODKA BADAŃ NAD KULTURĄ ORMIAŃSKĄ W POLSCE PRZY POLSKIEJ AKADEMII UMIEJĘTNOŚCI W KRAKOWIE
}

W sobotę 21 września 2019 roku w Librarii Collegium Maius, historycznego budynku Uniwersytetu Jagiellońskiego, odbyła się inauguracja prac Ośrodka Badań nad Kulturą Ormiańską w Polsce przy Polskiej Akademii Umiejętności. Zebranych powitał gospodarz miejsca, prof. Krzysztof Stopka, dyrektor Muzeum UJ i współzałożyciel Ośrodka.

W zgromadzeniu inauguracyjnym uczestniczyło blisko 80 zaproszonych osób, w tym prezes PAU prof. Jan Ostrowski i członkowie Rady Ośrodka (przedstawieni poniżej), a także: prof. Franciszek Ziejka, były rektor UJ, prof. Jan Święch, dziekan Wydziału Historycznego UJ, Kaspar Karampetian, przewodniczący European Armenian Federation for Justice and Democracy w Brukseli, prof. Valentina Calzolari Bouvier z Centre de recherches arménologiques przy Université de Genève, przewodnicząca Association pour l'Etude de la littérature apocryphe chrétienne i Association Internationale des Etudes Arméniennes, dr Harutyun Marutyan, dyrektor Muzeum-Instytutu Ludobójstwa Ormiańskiego (Zujng gtiuuuuuinıpjui puiquinuid-hquunhunnın) w Erywaniu, dr Bálint Kovács z Katedry Armenologii (Örmény Tanulmányok Tanszék) Katolickiego Uniwersytetu im. Pétera Pázmány’ego (Pázmány Péter Katolikus Egyetem), wardapet Wahan Ohanian z klasztoru oo. Mechitarystów w Wenecji, mitrat Henryk Błaszczyk z Ordynariatu Kościoła ormiańskokatolickiego na Ukrainie (Odessa - Kijów), prof. Józef Wołczański z Uniwersytetu Papieskiego Jana Pawła II w Krakowie, o. Marek Miławicki OP, badacz historii kościelnej Ormian polskich z Wrocławia, Maria Ohanowicz-Tarasiuk, prezes Fundacji Kultury 
i Dziedzictwa Ormian Polskich w Warszawie, dr Tomasz Knothe, były ambasador RP w Erywaniu, dr Maksym Potapenko z Nieżyńskiego Uniwersytetu Państwowego im. Mikołaja Gogola (Ніжинський державний університет ім. М. В. Гоголя), Hrair Hawk Khatcherian, znany fotograf ormiański z Kanady, Andrzej Urbański, dyrektor Muzeum w Zamościu, Anna Piontek z Muzeum w Gliwicach. Listy gratulacyjne i pozdrowienia nadeszły od Wojciecha Kolarskiego, ministra w Kancelarii Prezydenta RP, Pawła Cieplaka, obecnego ambasadora RP w Erywaniu, Edgara Ghazaryana, byłego ambasadora Republiki Armenii w Warszawie, obecnie dyrektora Sądu Konstytucyjnego Republiki Armenii w Erywaniu (pełny tekst poniżej), ks. Krzysztofa Nitkiewicza, biskupa sandomierskiego, Razmika Panosyana z Fundacji Calusta Gulbenkiana (Fundação Calouste Gulbenkian) w Lizbonie, Nicolasa Tavitiana, dyrektora Armenian General Benevolent Union Europe w Brukseli.

Jako pierwszy głos zabrał prezes PAU prof. Ostrowski, który powiedział m.in.: „Ormianie są związani z historią Polski przynajmniej od XIV wieku. Ich ważne dokonania to rozwój handlu wschodniego, stworzenie we Lwowie ośrodka rzemiosła artystycznego pracującego na rzecz całego kraju, wreszcie - w XIX i XX wieku - wkład w podniesienie kultury rolnej. Na dawnych polskich ziemiach wschodnich stoi kilkanaście kościołów wzniesionych przez wspólnotę ormiańską, które zostały świetnie opracowane przez mojego ucznia dra hab. Jacka Chrząszczewskiego i dr Joannę Wolańską. Polscy Ormianie modelowo wtopili się $\mathrm{w}$ polskie społeczeństwo, zajmując $\mathrm{w}$ jego ramach wysoką pozycję i dając świadectwo patriotyzmu w trudnych okolicznościach politycznych XX wieku. W większości przyjęli język polski, ale są rozpoznawalni dzięki nazwiskom i zachowali silną świadomość swego pochodzenia. Badania nad tradycją ormiańską są obowiązkiem polskiego środowiska naukowego. Cieszę się, że obecnie uzyskują ramy formalne i wsparcie ze strony wybitnych osobistości z całego świata, które przyjęły obowiązki uczestniczenia w Radzie Ośrodka".

Następnie program Ośrodka przedstawił piszący te słowa.

Ośrodek Badań nad Kulturą Ormiańską zrodził się na fundamencie dawnego i współczesnego dorobku krakowskich armenologów i armenistów. W ostatnich czasach ich działania były wspierane zarówno przez część środowiska naukowego - w tym miejscu trzeba wspomnieć zwłaszcza Jerzego Wyrozumskiego, historyka z Uniwersytetu Jagiellońskiego, potem sekretarza generalnego Polskiej Akademii Umiejętności - jak też społeczność Ormian polskich. To dwojakie wsparcie stanowiło nieocenioną motywację starań o utworzenie właśnie w Krakowie placówki dedykowanej badaniom armenologicznym, bo świadczyło o ich naukowej i społecznej potrzebie. W tej atmosferze zrodziły się w ostatnich kilku latach ważne dla polskiej armenologii inicjatywy - czasopismo „Lehahayer”, poświęcone dziejom Ormian polskich, wspierane finansowo przede wszystkim przez Fundację Lanckorońskich, a także Uniwersytet Jagielloński i Fundację 
Gumińskich (w tym roku ukazuje się już szósty rocznik), oraz seria źródłowa Pomniki dziejowe Ormian polskich, realizowana pod opieką Fundacji Kultury i Dziedzictwa Ormian Polskich dzięki grantowi Narodowego Programu Rozwoju Humanistyki. Pod względem organizacyjnym były to jednak działania na poły prywatne, rzec można - partyzanckie. Z chwilą powstania Ośrodka ulegają instytucjonalizacji.

Starania o utworzenie Ośrodka trwały od 2014 roku. Wsparli je swymi rekomendacjami pisemnymi lub ustnymi: prof. Franciszek Ziejka (UJ), prof. Krzysztof Penderecki (PAU), prof. Claude Mutafian (Université Paris XIII), prof. Andrzej Pisowicz (UJ), prof. Andrzej Nowak (UJ), prof. S. Peter Cowe (University of California Los Angeles), Edward Mier-Jędrzejowicz (przedstawiciel mniejszości ormiańskiej w Komisji Wspólnej Rządu RP i Mniejszości Narodowych), Armen Artwich (wtedy dyrektor Departamentu Prawnego w Kancelarii Prezesa Rady Ministrów RP). W PAU idea ta spotkała się z życzliwym przyjęciem ze strony wspomnianego już prof. Wyrozumskiego oraz obecnego prezesa prof. Ostrowskiego. Pomocy w staraniach udzieliła też Anna Michalewicz, dyrektor Biura i Portfela Projektów PAU. Oczywiście kluczowa była pozytywna decyzja ministra nauki i szkolnictwa wyższego i wicepremiera jednocześnie dra Jarosława Gowina, podjęta w kwietniu 2019 roku, o wyasygnowaniu subwencji na utworzenie Ośrodka. Dowodzi ona troski obecnego polskiego rządu o dziedzictwo mniejszości narodowych historycznej Rzeczypospolitej, obejmującej też ziemie dawnego Wielkiego Księstwa Litewskiego.

Kolejne etapy zakładania Ośrodka to uchwała Rady PAU o jego powołaniu, podjęta 10 września 2019 roku, oraz przyjęcie 23 października przez to samo grono statutu Ośrodka. Oba te działania przebiegały przy udziale prezesa prof. Ostrowskiego, sekretarza generalnego prof. Szczepana Bilińskiego oraz członków zarządu PAU, w tym wiceprezesa PAU Andrzeja Mączyńskiego.

Tworzenie Ośrodka wymaga współpracy ze środowiskami armenologicznymi w bliższym i dalszym sąsiedztwie, zwłaszcza w Warszawie, Budapeszcie, Kluż-Napoce, Mińsku, Lwowie, Kijowie, Erywaniu. Bezdyskusyjna jest bowiem potrzeba badań porównawczych nad spokrewnionymi ze sobą wspólnotami ormiańskiej diaspory w Polsce, Siedmiogrodzie, na Białorusi, Pokuciu, Bukowinie, dalszej Ukrainie. Czyli nad tymi Ormianami, których nazywamy nieco żartobliwie ,plemieniem hurutowym”, ze względu na wspólne upodobanie do zupy gandżabur wyrabianej z hurutu, albo „ludem barankowym” z uwagi na popularność wśród ormiańskich gmin i rodów w całej środkowoeuropejskiej ojczyźnie znaku herbowego „Angelus cum labaro”.

Kwerendy archiwalne, badania analityczne i upowszechnienie ich wyników to główne formy pracy Ośrodka. W tych zakresach nie startuje od zera. Kontynuować będzie dwa wspomniane już przedsięwzięcia edytorskie: rocznik „Lehahahyer" i serię źródłową Pomniki dziejowe Ormian Polskich. Do nich doszła seria 
wydawnicza pt. Biblioteka „Lehahayer” Wydawcą ich wszystkich pozostaje krakowska oficyna Księgarnia Akademicka.

Ośrodek zamierza też współtworzyć instrumentarium badawcze dla polskiej armenologii: bibliografie i słowniki biograficzne, digitalizowanie zagrożonych zniszczeniem źródeł archiwalnych. W planach jest stworzenie w formie elektronicznej anglojęzycznej naukowej Encyklopedii Ormian Polskich, analogicznej do takich wydawnictw, jak Encyclopaedia Judaica, Encyclopaedia Iranica, Encyclopedia of Ukraine ${ }^{2}$.

Oczywiście, każdy z pracowników Ośrodka ma też realizować lub kontynuować indywidualne badania nad dziejami Ormian we Lwowie, Kamieńcu Podolskim, Lublinie i innych ośrodkach osadniczych, nad Kościołem, szlachtą pochodzenia ormiańskiego, martyrologią Ormian polskich na dawnych Kresach Wschodnich w czasach drugiej wojny światowej, stosunkami między Polską i Armenią oraz polską reakcją na ludobójstwo Ormian w Imperium Osmańskim.

Ponieważ Ośrodek jest dopiero w stadium tworzenia i ma ograniczony budżet, nie może zatrudnić wszystkich chętnych badaczy zajmujących się dziejami Ormian polskich i różnymi aspektami kultury ormiańskiej. Mamy nadzieję, że w przyszłości nasz zespół ulegnie powiększeniu, ale na razie stałą współpracę z Ośrodkiem, oprócz prof. Krzysztofa Stopki i niżej podpisanego, podejmą dok-

${ }^{1}$ Serią kierują Krzysztof Stopka i niżej podpisany. Do jego komitetu redaktorskiego zaproszeni zostali: prof. Andrzej Pisowicz (Kraków), prof. Judit Pál (Kluż-Napoka), prof. Petr Kaleta (Brno), dr Tatevik Sargsyan (Symferopol), o. Wahan Ohanian (Wenecja). Dwa pierwsze tomy, skierowane już do druku, są autorstwa Jakuba Osieckiego (Apostolski Kościól Ormiański w Armenii sowieckiej 1920-1932) i Tomasza Krzyżowskiego (Archidiecezja lwowska obrząku ormiańskokatolickiego w latach 1902-1938).

${ }^{2}$ Wszystkie trzy wspomniane tu encyklopedie systematyzują olbrzymią wiedzę w swych dziedzinach, są inicjatywami gromadzącymi wielu współpracowników, mającymi znaczące wsparcie finansowe, ale też poświęcone są problematykom znacznie szerszym niż dzieje polskich Ormian. Encyclopaedia Judaica ukazała się po raz pierwszy w latach 1971-1972 w 16 tomach (Jerozolima-Nowy Jork), została następnie poszerzona o kilkanaście tomów uzupełnień (1973-1992). Jej redaktorami byli kolejno Cecil Roth i Geoffrey Wigoder. Druga edycja pojawiła się na przełomie lat 2006 i 2007 (22 tomów, redaktor: Fred Skolnik). Żadna z tych edycji nie posiada wersji elektronicznej. Ma ją, choć tylko częściowo, Encyclopaedia Iranica (www.iranicaonline.org), wydawana od 1983 roku przez Centrum Studiów Irańskich przy Columbia University oraz Encyclopaedia Iranica Foundation (aktualnie obie te instytucje spierają się ze sobą w nowojorskim sądzie) pod redakcją międzynarodowego komitetu, kierowanego przez Ehsana Yarshatera i Ahmada Ashrafa. Do tej pory ukazało się 16 tomów (do litery K), ostatni w 2013 roku. Internet Encyclopedia of Ukraine (http://www.encyclopediaofukraine.com) jest przygotowywana przez zespół Canadian Institute of Ukrainian Studies (University of Alberta / University of Toronto) i stanowi poprawioną wersję książkowej, pięciotomowej Encyclopedia of Ukraine (Toronto 1984-1993), przygotowanej przez CIUS we współpracy z Canadian Foundation for Ukrainian Studies i Shevchenko Scientific Society in Western Europe, pod redakcją Wołodymyra Kubijowycza (1978-1985) i Danyly Husara Struka (1985-1999). 
torzy: Jakub Osiecki, absolwent Uniwersytetu Jagiellońskiego, specjalizujący się w dziejach najnowszych Kościoła w Armenii i relacjach politycznych polsko-ormiańskich w wieku XX; Franciszek Wasyl, absolwent Uniwersytetu Rzeszowskiego, autor prac z zakresu demografii historycznej Ormian w austriackiej Galicji; Marcin Łukasz Majewski, absolwent Katolickiego Uniwersytetu Lubelskiego, historyk miast, autor pracy o Ormianach w Piotrkowie Trybunalskim, oraz Tomasz Krzyżowski, absolwent Papieskiego Uniwersytetu Jana Pawła II w Krakowie, specjalista w zakresie dziejów Kościoła ormiańskokatolickiego w Polsce w XIX i XX wieku, autor monografii lwowskiej archidiecezji ormiańskokatolickiej w czasach arcybiskupa Józefa Teodorowicza.

W pracach nad wspomnianymi wyżej projektami wspierać ma Ośrodek jego Rada, w której skład zgodzili się wejść zarówno wybitni uczeni, jak też przedstawiciele Ormian polskich i instytucji promujących badania armenologiczne. Są to (w porządku alfabetycznym): Monika Agopsowicz, członek Rady Fundacji Kultury i Dziedzictwa Ormian Polskich (Warszawa), autorka prac historycznych o Ormianach polskich; prof. George Bournoutian, historyk, armenolog, iranista, wykładowca w Iona College (Nowy Jork), współredaktor Encyclopaedia Iranica, wcześniej wykładowca University of California Los Angeles, Columbia University, Tufts University, New York University, Rutgers University; Armen Checzojan, dyrektor generalny Fundacji Wspierania Studiów Armenistycznych „Aniw” (Фонд развития и поддержки арменоведческих исследований „Анив”, Mińsk - Moskwa - Erywań), inspirator wielu projektów translatorskich, konferencyjnych i badawczych w Rosji, Armenii, Białorusi, a także w Polsce; prof. Armenuhi Drost-Abgarjan, wybitna badaczka chrześcijańskiego Orientu i kultury bizantyjskiej, armenolog, wykładowczyni Martin-Luther-Universität Halle-Wittenberg (Orientalisches Institut, Seminar Christlicher Orient und Byzanz, Arbeitsstelle für Armenische Studien); prof. Armen Edigarian, matematyk, pracownik Katedry Analizy Matematycznej oraz prorektor UJ; Zbigniew Manugiewicz, przewodniczący Rady Nadzorczej korporacji PMP Group, współautor książki - bestsellera - o miasteczku Kuty nad Czeremoszem, mateczniku wielu Ormian współcześnie mieszkających w Polsce; prof. Lidia Matynian, chórmistrzyni, dyrektor Instytutu Dyrygentury Chóralnej, Edukacji Muzycznej i Rytmiki w Akademii Muzycznej w Krakowie, b. prorektor tej uczelni, dyrygent i kierownik Chóru Chłopięcego Filharmonii im. Karola Szymanowskiego; Edward Mier-Jędrzejowicz, przedstawiciel mniejszości ormiańskiej w Komisji Wspólnej Rządu Rzeczypospolitej Polskiej i Mniejszości Narodowych i Etnicznych, ambasador Zakonu Maltańskiego w Republice Cypru, prezes Fundacji Gumińskich; prof. Claude Mutafian, historyk, armenolog, matematyk, wykładowca Université Paris XIII, członek zagraniczny Narodowej Akademii Nauk

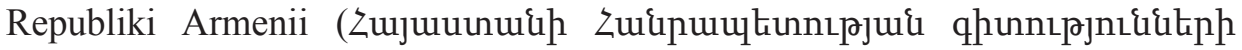
uqqujhq ulquintư(pu), oddany i wieloletni przyjaciel polskich badań armeno- 
logicznych; prof. Józef Naumowicz, historyk literatury wczesnochrześcijańskiej, patrolog, bizantynolog, kierownik Katedry Historii Starożytnej w Uniwersytecie Kardynała Stefana Wyszyńskiego (Warszawa), wiceprzewodniczący Komisji Bizantynologicznej PAN, redaktor naczelny serii Studia Antiquitatis Christianae i Biblioteka Ojców Kościoła, proboszcz ormiańskokatolickiej parafii centralnej pw. św. Grzegorza z Nareku w Warszawie; prof. Judit Pál, historyk, specjalistka w zakresie dziejów Siedmiogrodu, zwłaszcza stosunków etnicznych, autorka prac o dziejach Ormian siedmiogrodzkich, wykładowca Wydziału Historii Uniwersytetu Babeșa i Bolyaia (Universitatea Babeș-Bolyai / Babeș-Bolyai Tudományegyetem) w Kluż-Napoce; prof. Andrzej Pisowicz, armenista i iranista, nestor krakowskiej armenistyki, członek Collegium Invisibile, b. kierownik Zakładu Iranistyki i b. wicedyrektor Instytutu Orientalistyki UJ, redaktor „Biuletynu Ormiańskiego Towarzystwa Kulturalnego"; prof. Ara Sayegh, wykładowca Politechniki Wrocławskiej, prezes Ormiańskiego Komitetu Narodowego Polski; prof. Ewa Siemieniec-Gołaś, językoznawca, kierownik Zakładu Turkologii w Instytucie Orientalistyki UJ, członek Komitetu Nauk Orientalistycznych Polskiej Akademii Nauk, wiceprezes Polskiego Towarzystwa Orientalistycznego; prof. Krzysztof Stopka, historyk, kierownik Zakładu Historii Kultury i Edukacji Historycznej w Instytucie Historii UJ, dyrektor Muzeum UJ, przewodniczący Komisji Wschodnioeuropejskiej PAU, redaktor naczelny czasopisma „Lehahahyer”.

W dyskusji głos zabrali: Edward Mier-Jędrzejowicz, prof. Calzonari, prof. Bournoutian, prof. Drost Abgarjan, prof. Naumowicz, Armen Checzojan, ks. Błaszczyk. Ponadto prelekcję o reprezentowanym przez siebie muzeum przedstawił dr Harutyun Marutyan. Po przerwie wykład inauguracyjny wygłosił gość specjalny, wardapet Wahan Ohanian z Wenecji. Przedstawił w nim sylwetkę wybitnego armenologa dziewiętnastowiecznego Ghewonda Aliszana, mechitarysty, poety romantycznego i narodowego wizjonera. Rozszerzoną wersję odczytu zamieszczamy w niniejszym tomie „Lehahayer”.

Inauguracji towarzyszył pokaz zabytków ormiańskich przechowywanych w Muzeum UJ. Były to portrety olejne ksień benedyktynek ormiańskich ze Lwowa (depozyt Fundacji Kultury i Dziedzictwa Ormian Polskich) oraz welum z klasztoru w Muszu (zob. artykuł na jego temat w 5 tomie „Lehahayer”). Treści kulturowe tego ostatniego artefaktu objaśniali Joanna Sławińska i dr Osiecki. Ponadto goście zagraniczni mieli okazję zapoznać się z kolekcją armeników Biblioteki Książąt Czartoryskich, o których opowiadał prof. Stopka. Kolekcja wzbudziła wielkie zainteresowanie. Niektóre z cennych rękopisów zostały sfotografowane przez Hraira Hawka Khatcheriana i wejdą do przygotowywanego przez niego albumu obrazującego skarby iluminowanych ksiąg rękopiśmiennych dawnej Armenii.

Ośrodek wzbogacił się już podczas inauguracji o dary ofiarowane przez gości, w tym dzieło malarskie Romana Łysakowskiego (1899-1992), artysty rodzin- 
nie powiązanego z Ormianami polskimi (rody Krzeczunowiczów i Agopsowiczów), przekazane przez jego córkę, p. Elżbietę Łysakowską z Wrocławia, oraz liczne książki.

\section{Andrzej A. Zięba, Inauguration of the Research Centre for Armenian Culture in Poland as a part of the Polish Academy of Arts and Sciences in Krakow}

The inauguration of the Research Centre for Armenian Culture took place on January 21, 2019 at the Collegium Maius of the Jagiellonian University in Krakow.

The Centre was founded on the basis of old and contemporary achievements of Kraków armenologists and armenists. They were accompanied by the constant interest of Polish Armenians - from Kraków, Warsaw, Gdańsk, Lower and Upper Silesia. Such support was invaluable in the efforts to create the Centre, because it demonstrated not only the scientific but also the social need for research in this field. In this atmosphere, in recent years, important initiatives for Polish armenology were born - the magazine Lehahayer, devoted to the history of Polish Armenians, financially supported by the Lanckoroński Foundation, the Jagiellonian University and the Gumiński Foundation (this year, the 6th edition will be released), and a series of archival sources, Historical Monuments of Polish Armenians, implemented under the care of the Foundation for Culture and Heritage of Polish Armenians thanks to a grant from the National Humanities Development Program. In organizational terms, however, these activities were semi-private or, so to speak, partisan. They were institutionalized when the Centre was founded.

Efforts to create the Centre began in 2014. They were supported by written and oral recommendations from prof. Franciszek Ziejka, prof. Krzysztof Penderecki, prof. Claude Mutafian, prof. Andrzej Pisowicz, prof. Andrzej Nowak, prof. Peter Cowe, Mr. Edward Mier-Jędrzejowicz, and Mr. Armen Artwich. At the Polish Academy of Arts and Sciences we met with a friendly reception from prof. Jerzy Wyrozumski, secretary general, and prof. Jan Ostrowski, the current president. Of course, we would not be here if not for the positive decision of the Minister of Science and Higher Education and the Deputy Prime Minister, Jarosław Gowin. This decision determined that the Centre would be created. It proves the current Polish government's concern for the heritage of national minorities of the historical Polish Commonwealth, including the lands of the old Grand Duchy of Lithuania.

We count on the continued support of all these people and institutions. We want to cooperate in the construction of the Centre with armenological institutions in the close and distant neighborhood: Budapest, Cluj-Napoka, Minsk, Kyiv, Lviv. We see the need for comparative research on related communities of the Armenian diaspora in Poland, Transylvania, Belarus, Pokucie, Bukovina, and Ukraine. That is, over those Armenians, whom we call somewhat jokingly a «hurut tribe» due to a common taste for ganjabur soup made from hurut, or «lamb people» due to the popularity of the Angelus cum labaro coat of arms among Armenian communities and families throughout the whole Central European homeland.

Archival queries, analytical research and the dissemination of its results are the main forms of the Centre's work. We do not start from zero level. We will continue 
the two already mentioned ventures of our research milieu: editing the annual Lehahahyer and editing historical sources in the series Historical monuments of Polish Armenians. We also want to participate in the creation of research instruments for Polish armenology: bibliographies and biographical dictionaries, digitizing archival sources threatened by destruction. We also plan to create an electronic English-language scientific Encyclopedia of Polish Armenians. Of course, each of the Centre's employees will also carry out or continue individual research, including the history of the Armenians in Lviv, Kamieniec Podolski, Lublin and other settlement centres, the Church, the nobility of Armenian origin, the martyrdom of Polish Armenians in the former Eastern Borderlands during the Second World War, the relations between Poland and Armenia and the Polish response to the Armenian genocide in the Ottoman Empire.

Since the Centre is only at the stage of creation and has a limited budget, it cannot employ all researchers who are willing to deal with the history of Polish Armenians and various aspects of Armenian culture. For now, the following persons with doctoral degrees will cooperate with the Centre on a permanent basis: Jakub Osiecki, graduate of the Jagiellonian University, specializing in the history of the Armenian Church and Polish-Armenian political relations in the 20th century; Franciszek Wasyl, graduate of the University of Rzeszów, author of works in the field of historical demography of Armenians in Austrian Galicia; Marcin Łukasz Majewski, graduate of the Catholic University of Lublin, historian of cities and urban bourgeoisie and author of the work on Armenians in Piotrków Trybunalski; Tomasz Krzyżowski, graduate of the Pontifical University of John Paul II in Krakow, specialist in the history of the Armenian Catholic Church in Poland in the 19th and 20th centuries.

In the work on the projects mentioned above, we count on the support of the members of the Centre's Council, which includes both eminent scholars and representatives of Polish Armenians and institutions supporting armenological research in our part of Europe. These are (in alphabetical order): Monika Agopsowicz, member of the Council of the Foundation for Culture and Heritage of Polish Armenians in Warsaw, author of historical publications on Polish Armenians; prof. George Bournoutian, historian, armenologist, specialist in Iranian studies, lecturer at Iona College, co-editor of Encyclopaedia Iranica; prof. Armenuchi Drost-Abgarjan, an outstanding researcher of the Christian Orient and Byzantine culture, armenologist, lecturer at Martin-Luther-Universität Halle-Wittenberg; prof. Armen Edigarian, mathematician, vice rector of the Jagiellonian University; Armen Khechoyan, general director of the Aniv Foundation for Support of Armenian Studies (Minsk-Moscow-Yerevan); Zbigniew Manugiewicz, chairman of the Supervisory Board of the PMP Group corporation, co-author of the bestselling book about the town of Kuty on Pokucie, which was the motherland of many Armenians living in Poland today; prof. Lidia Matynian, director of the Institute of Choir Conducting, Music Education and Rhythmics at the Academy of Music in Kraków, former vice-rector of this Academy, conductor and head of the Boys' Philharmonic Choir; Edward Mier-Jędrzejowicz, a representative of the Armenian minority in the Joint Commission of the Government of the Republic of Poland and National and Ethnic Minorities, ambassador of the Order of Malta in the Republic of Cyprus; prof. Claude Mutafian, historian, 
armenologist, mathematician, lecturer at Université Paris XIII, foreign member of the National Academy of Sciences of the Republic of Armenia; prof. Józef Naumowicz, patrologist, byzantologist, head of the Department of Ancient History at the Cardinal Stefan Wyszyński University in Warsaw, deputy chairman of the Byzantine Commission of the Polish Academy of Sciences, rector of the Armenian Catholic St. Grigor Narekatsi parish in Warsaw; prof. Judit Pál, historian, specialist in the history and ethnic relations of Transylvania, author of works on the history of Transylvanian Armenians, lecturer at the Faculty of History of the Babeş-Bolyai University in Cluj-Napoca; prof. Andrzej Pisowicz, specialist in Armenian and Iranian philology, nestor of Krakow Armenian studies, former head of the Chair of Iranian Studies and former deputy director of the Institute of Oriental Studies of the Jagiellonian University; prof. Ara Sayegh, from the Wrocław University of Technology, president of the Armenian National Committee of Poland; prof. Ewa SiemieniecGołaś, linguist, head of the Chair of Turkology at the Institute of Oriental Studies of the Jagiellonian University, member of the Committee for Oriental Studies of the Polish Academy of Sciences, vice president of the Polish Orientalist Society; prof. Krzysztof Stopka, historian, head of the Chair of History of Culture and Historical Education at the Institute of History of the Jagiellonian University, director of the Jagiellonian University Museum, chairman of the East European Commission of the Polish Academy of Arts and Sciences. 